\title{
HARROUDJ V. FRANCE: INDICATIONS FROM THE EUROPEAN COURT OF HUMAN RIGHTS ON THE NATURE OF CHOICE OF LAW RULES AND ON THEIR POTENTIALLY DISCRIMINATORY EFFECT
}

\author{
Patrick KINSCH ${ }^{*}$
}

An article published in the 2011 edition of this Yearbook ${ }^{1}$ sought to provide a general description of the European human rights protection mechanism and of its application to private international law topics. In the two years since publication of that article there have been a significant number of judgments and decisions by the European Court of Human Rights touching on matters of private international law, ${ }^{2}$ including an important decision by which the Court has preserved - for the time being at least - the EU European Enforcement Title mechanism as applied to the Brussels II-bis Regulation, and thereby a central part of the EU's "free movement of judgments" programme, from challenge under the European Convention on Human Rights. ${ }^{3}$

" Of the Luxembourg Bar; Professor, University of Luxembourg.

${ }^{1} \mathrm{P}$. Kinsch, Private International Law Topics Before the European Court of Human Rights - Selected Judgments and Decisions (2010-2011), YPIL Vol. 13 (2011), p. 37 et seq.

${ }^{2}$ The more original judgments during the years 2012 and 2013 appear to be (apart from the Povse v. Austria decision mentioned in the next footnote) Granos Organicos Nacionales S.A. v. Germany, judgment of 22 March 2012, No 19508/07 (no violation of the non-discrimination provision of Article 14 of the Convention, in combination with the right to access to a court, by the decision of a German court denying legal aid to the applicant company for the purposes of a claim that it intended to bring before a German court; the denial of legal aid was grounded on the applicant's foreign nationality: this rule of German law was held to be justified by "the principle of reciprocity") and X. v. Latvia [GC], judgment of 26 November 2013, No 27853/09, confirming the chamber judgment of 13 December 2001 (see YPIL Vol. 13 (2011), p. 47-48).

${ }^{3}$ See the decision of 18 June 2013, Sofia and Doris Povse v. Austria, No 3890/11. In that case the Court rejected an application against Austria for having enforced an Italian order for the return of a child to Italy obtained by her father. The order had been enforced, as required under Article 42 of Council Regulation (EC) No. 2201/2003 ("Brussels II-bis"), "without any possibility of opposing its recognition" and therefore without any review by the Austrian courts (see also the preliminary ruling by the ECJ, C-211/10 PPU, Doris Povse v. Mauro Alpago, [2010] ECR I-6673), something that usually goes against the by now wellestablished jurisprudence of the European Court of Human Rights construing the right to family life under Article 8 of the Convention (see, in cases involving the return of children to Israel, Neulinger and Shuruk v. Switzerland, judgment of 6 July 2010 [GC], No 41615/07, and to Australia, X. v. Latvia, preceding note). In Povse however, the Court extended to the Brussels II-bis Regulation its holding in Bosphorus Hava Yolları Turizm ve

Yearbook of Private International Law, Volume 15 (2013/2014), pp. 39-44

(C) sellier european law publishers \& Swiss Institute of Comparative Law

Printed in Germany 


\section{Patrick Kinsch}

This article concentrates on another recent judgment of the Court. It does not consider the issues of judgment recognition which, for the time being, tend to be the private international law issues most commonly dealt with by the Court. It deals with fundamental questions of choice of law.

1. In Harroudj v. France, ${ }^{4}$ the question at issue was a denial by the French courts of a request for adoption. A French national, Ms Harroudj, had been authorized by an Algerian court to take a child, Hind (then aged three months), into her legal care (kafala). The court also authorised the child to leave Algeria with Ms Harroudj and settle in France; another Algerian court authorised the change of the child's name to Hind Harroudj. Two years later, Ms Harroudj applied in France for full adoption of the child, arguing that a full adoption was the solution most consistent with "the best interests of the child", within the meaning of Article $3 \S 1$ of the Convention on the Rights of the Child of 20 November 1989 and Article 1 of the Hague Convention of 29 May 1993 on Protection of Children and Co-operation in Respect of Intercountry Adoption. This request was denied: adoption is a valid concept under the law of France but it is not valid under Algerian law which, in accordance with Islamic law, expressly prohibits it. ${ }^{5}$ Kafala is not equivalent to adoption. Under a choice of law rule introduced into the French Code civil (as Article 370-3) by a law of 6 February 2001,

"The requirements for adoption are governed by the national law of the adopter or, in case of adoption by two spouses, by the law which governs the effects of their marital relationship. Adoption, however, may not be granted where it is prohibited by the national laws of both spouses.

Adoption of a foreign minor may not be ordered where his or her personal law prohibits that institution, unless the minor was born and resides habitually in France...”6

Ticaret Anonim Şirketi v. Ireland [GC] (judgment of 30 June 2005, No 45036/98, ECHR 2005-VI), which had shown the willingness of the Court to leave the obligations of the contracting States under European Union law undisturbed, as long as the standard of human rights protection under EU law could be recognized as equivalent to the protection afforded under the ECHR. - In a later case (Avotinšs v. Latvia, judgment of 25 February 2014, No 17502/07) the Court applied similar reasoning to the recognition in Latvia of a Cypriot judgment under the Brussels I Regulation: Article 34(2) of the Brussels I Regulation was allowed to prevail over the fair-trial rights of the defendant to the Cyprus proceedings, who had failed to exercise an appeal in Cyprus against a default judgment entered against him and declared enforceable in Latvia.

${ }^{4}$ Judgment of 4 October 2012, No 43631/09.

${ }^{5}$ Article 46 of the Algerian Family Code: “Adoption (tabanni) is prohibited by the Sharia and by legislation."

${ }^{6}$ Before that law, the French private international law of adoption was much more flexible and allowed children given in kafala to be adopted once they had arrived in France, under the condition of the "consent" of the minor's representative "having regard to the effects attached by French law to adoption and, in particular, in the case of full adoption, to the complete and irrevocable nature of the severance of the relationship between the minor 
Since Hind was not adoptable under her national law, Ms Harrouj's adoption request was denied. Ms Harroudj subsequently brought an application against France alleging violation of Article 8 of the Convention (right to family life) and Article 14 in combination with Article 8 (discrimination in the enjoyment of family life) - the argument for this latter ground for the application was based on the fact that while the applicant could not adopt Hind, there was no obstacle to the adoption of other children, whose national law did not prohibit adoption.

2. The Court approached the claim that the applicant's right to family life had been violated by first pointing out that family life indeed existed between Ms Harroudj and the child. What was disputed was whether there was, in addition, a positive obligation for the French authorities to recognise a legal parent-child relationship by granting the applicant's request for full adoption of Hind. In that respect, the Court found that the French authorities had a broad margin of appreciation ${ }^{7}$ and the Court ultimately considered that "the applicant met with refusal largely on account of a concern to abide by the spirit and purpose of international conventions". By this it meant the UN Convention on the Rights of the Child of 20 November 1989, Article 20 of which puts on the same plane (and considers as in accordance with the best interests of the child) adoption and kafala under Islamic law, and the Hague Conventions of 29 May 1993 on Protection of Children and Co-operation in Respect of Intercountry Adoption and of 19 October 1996 on Jurisdiction, Applicable Law, Recognition, Enforcement and Cooperation in Respect of Parental Responsibility and Measures to Protect Children, all of which are based on the same logic. According to the Court, "the recognition of kafala by international law is a decisive factor in assessing how States deal with it in their national laws and envisage any choice-of-law issues that may arise.”

Next, the Court noted that although some differences between kafala and adoption are insurmountable (especially the fact that kafala "has no effects for inheritance"), the restrictions engendered by the impossibility of adopting the child can be remedied to some extent. The Court therefore concluded as follows:

"The respondent State, applying the international conventions that govern such matters, has put in place a flexible arrangement to

and his blood relatives or the guardianship authorities of his country of origin" (Cour de Cassation, Civ. $1^{\text {re }} 10$ May 1995, Rev. crit. dr. int. pr. 1995, p. 547, with annotation by $\mathrm{H}$. MuIR WATT). But, since the minor's representative frequently was a public authority assuming the function of guardian over an abandoned child, this solution was tantamount to accepting the consent of the child's representative even given in error or illegally under the child's (and the representative's) national law. On the 2001 law, see generally P. LAGARDE, La loi du 6 février 2001 relative à l'adoption international: une opportune clarification, Rev. crit. dr. int. pr. 2001, p. 275 et seq.; H. MUIR WATT, La loi nationale de l'enfant comme métaphore: le nouveau régime législatif de l'adoption internationale, Clunet 2001, p. 995 et seq.

${ }^{7} \S 47-48$. The "broad margin of appreciation" existed in view of the considerable differences between the private international law systems of the various member states of the Council of Europe on the proper approach to the choice of law in adoption matters generally and, specifically, to the role of a preexisting kafala in an adoption (see $\S \S 21$ and 22 for a summary of the comparative material on which the Court relies). 
accommodate the law of the child's State of origin and the national law. The Court notes that the prohibition of adoption stems from the choice-of-law rule in Article 370-3 of the Civil Code but that French law provides the means to alleviate the effects of that prohibition, based on the objective signs of a child's integration into French society. Firstly, the choice-of-law rule is expressly set aside by the same Article 370-3 in cases where "the minor was born and habitually resides in France”. Secondly, this choice-of-law rule is deliberately circumvented by the possibility for the child to obtain French nationality, within a reduced period of time, and thus to be adopted, when he or she has been in the care of a French national. The Court observes in this connection that the respondent State argued, without being contradicted, that Hind could already benefit from such a possibility.

The Court takes the view that by gradually obviating the prohibition of adoption in this manner, the respondent State, which seeks to encourage the integration of children of foreign origin without cutting them off immediately from the rules of their country of origin, has shown respect for cultural pluralism and has struck a fair balance between the public interest and that of the applicant."”

As to the claim that the applicant's right to non-discrimination had been violated by submitting the adoptability of Hind to Algerian law (which made her unadoptable) while other children, subject to other national laws without the same types of restrictions on their adoptability, could be adopted in France, this was treated as an issue that did not call for separate treatment:

"The Government submitted that the alleged difference in treatment stemmed from an objective factor related to the child's personal law and in accordance with the child's best interests and that it was proportionate to the aim pursued.

In the Court's view, the gravamen of the applicant's complaint under Article 14 of the Convention is her inability to adopt Hind on account of the child's personal law. That issue has been examined under Article 8 and no violation thereof has been found. In those circumstances, the Court considers that no separate issue arises under Article 14 of the Convention and makes no separate finding."”

3. Harroudj is remarkable for the attention paid by the European Court of Human Rights to the aims pursued by private international law in general and by the submission of personal status to nationality in particular. It is the first, and so far the only judgment of the Court to enter into a serious discussion of those aims. While not being a mandatory consideration for a court deciding cases solely on the basis of the European Convention of Human Rights - rather it is sufficient if the

\footnotetext{
${ }^{8} \S 51$.

${ }^{9} \S 54-55$.
} 
Court correctly understands the operation of the rule and then assesses its consequences in view of the human rights norms relied upon -, nevertheless such concern and consideration is always welcome. The view of the private international law of family relationships that the Court approves of in the Harroudj case is the modern (or postmodern) view emphasising the individual's cultural identity and the links of that identity to his or her national origin, rather than the $19^{\text {th }}$ century view (also held by most private international lawyers for much of the $20^{\text {th }}$ century, for that matter) based on the State's interest in the uniform application of its law to its nationals. ${ }^{10}$ However it is also clear that the Court does not simply accept, without further review, the solutions provided for by national choice of law rules submitting the question of adoptability to Algerian law. It rules that the solutions of French private international law are compatible with the right to family life and therefore also with the right to non-discrimination, but only because they admit that eventually, in view of "the objective signs of a child's integration into French society", the substantial solution of French law (adoptability of the child) replaces the restrictive substantial solution of Algerian law, and that the connection to Algerian law is not immutable in case of subsequent acquisition of French nationality.

This also appears to mean that the Convention would have been violated if the French system of conflict of laws had proved excessively and unreasonably rigid and admitted no relaxation at all of the rule of non-adoptability of a child whose State of origin does not allow for adoption. Conflict of laws rules are a part of the legal system of the forum State; as such they cannot escape review in light of the human rights norms binding on that State. ${ }^{11}$ In particular, they cannot be said to be too abstract for such a review to be conducted. The fact that the child Hind could not be adopted by Ms Harroudj was that Algerian substantive law prohibits adoption as being against the Sharia, and Algeria is not a contracting State to the European Convention on Human Rights. France, on the other hand, is a contracting State and French conflict rules direct that Algerian law is to be applied in this case. That is the ultimate reason why the restrictive attitude of Algerian law can and will be subjected to review under the European Convention on Human Rights - not because Algeria would be bound by the Convention (it is not), but because France, by referring through its choice of law rules to the substantive solution of Algerian law (and by not displacing it as being against French public policy) gives it effectiveness in France.

Similar reasoning can be applied to the discrimination argument. This would not appear to be contradicted either by the fact that the French conflict rules

${ }^{10}$ An eminent proponent of the view that the Court thus shares is E. JAYME: Identité culturelle et integration - Le droit international privé postmoderne, Recueil des Cours vol. 251 (1995); idem, Kulturelle Identität und Kindeswohl im internationalen Kindschaftsrecht, IPRax 1996, p. 237 et seq.; idem, Die kulturelle Dimension des Rechts - Ihre Bedeutung für das Internationale Privatrecht und für die Rechtsvergleichung, RabelsZ 2003, p. 211 et seq.

11 That was the great contribution to private international law theory of the Spanierbeschluss, the important decision of the German Constitutional Court of 1971 (BVerfGE 31, 58) which deals with the issues raised by conflict rules and the applicable foreign law, as confronted to the fundamental rights defined by the German constitution. 


\section{Patrick Kinsch}

have no substantive content. ${ }^{12}$ Behind the solution adopted by the Court is the idea that there exist, not in French substantive law but still in France and in the French legal system as a whole, two rules of substantive law with respect to the adoptability of children: a rule of adoptability for children whose personal status is governed by a law which allows adoption, and a solution of non-adoptability for children of restrictive personal status. The scope of these two rules is determined by the French conflict rule. Thus, it seems that conflict rules are not, after all, immune from review under the rule of non-discrimination, just as the application of Algerian law designated by the conflict rule of French law is not immune from review in the light of the right to family life. ${ }^{13}$ The margin of appreciation of contracting States is a broad one, and no specific choice of law rule can be said to be mandated by the European Convention on Human Rights. However, if a choice of law rule should be seen as irrational, it will be held discriminatory.

12 See F. MARChADIER, Les objectifs généraux du droit international privé à l'épreuve de la Convention européenne des droits de l'homme, 2007, p. 272 et seq., and the nuanced position taken by J. MEEusen, Le droit international privé et le principe de nondiscrimination, Recueil des Cours vol. 353 (2011), p. 46. The present author admits that he has in the past taken another position, of which it might be thought that it gave excessive emphasis to the absence of substantive content of choice of law rules.

${ }^{13}$ This could also be seen as an illustration of the ideas, frequently dismissed as impractical, of Italian conflicts theorists of the first half of the $20^{\text {th }}$ century on the "reception" or "nationalisation" of foreign law through the forum's choice of law rules: see P. KINSCH, Sur la question de la discrimination inhérente aux règles de conflit de lois. Développements récents et interrogations permanentes, in Liber Amicorum Laura Picchio Forlati, Torino 2014. 